\title{
Structure changes in a planktonic food web: biotic and abiotic controls
}

\author{
Juan Manuel MEDINA-SÁNCHEZ, Manuel VILLAR-ARGAIZ, Pedro SÁNCHEZ-CASTILLO ${ }^{1)}$, \\ Luis CRUZ-PIZARRO ${ }^{1)}$ and Presentación CARRILLO ${ }^{1)}$ \\ Departamento de Biología Animal y Ecología, Universidad de Granada, 18071 Granada, Spain \\ ${ }^{1)}$ Instituto del Agua, Universidad de Granada, 18071 Granada, Spain \\ e-mail: pcl@goliat.ugr.es
}

\begin{abstract}
We examined the response of the plankton community to strong changes in the volume of oligotrophic Lake La Caldera through the ice-free period of 1995-1997. As consequence of the changes in the precipitation regime, the lake volume diminished to $2 \mathrm{~m}$ depth during the extremely dry year of 1995. The increase in phosphorus availability for this year caused the diversification of the planktonic community, and the autotrophic:heterotrophic $(\mathrm{A} / \mathrm{H})$ ratio was below 1 . In spite of the sporadic dust loads associated to atmospheric events, the quick recovery of the lake volumen in 1996 led to a severe phosphorus limitation. Phytoplankton community was dominated by Chrysophyceae (>90\% of abundance) and large zooplankters were very scarce $\left(<1\right.$ ind $\left.l^{-1}\right)$. As a consequence, A/H ratio was over 1 and ciliates developed. Finally, towards the end of 1997, the zooplankton recovery led to a decrease of both $\mathrm{A} / \mathrm{H}$ ratio and ciliates, and the lake returned to the conditions before drought. A decreasing tendency in both bacterial and phytoplankton densities, possibly as a consequence of top-down controls, was observed through the period of 1995-1997.
\end{abstract}

Key words: food web, taxonomic structure, seasonal and interannual variations

\section{INTRODUCTION}

High mountain oligotrophic lakes present simple planktonic communities which make them suitable to study complex interactions (Neill 1988). Oligotrophy promotes the existence of small sized phytoplankton species with high turnover rates (Reynolds 1984; Psenner \& Zapf 1990) and large-bodied zooplankton with low metabolic rates (Taylor 1984). Direct competition between phytoplankton and bacteria for mineral resources sets up an important interaction in these nutrient-limited systems (Currie 1990; Thingstad et al. 1993). It is accepted that microzooplankton and mixotrophic algae, through bacterivory, modulate the competition between algae and bacteria (Rothhaupt 1992; Nygaard \& Tobiesen 1993; Thingstad \& Rassoulzadegan 1995). Furthermore, metazooplankton can alter algal and bacterial communities through grazing (Elser \& Goldman 1991; Carrillo et al. 1995) or by increasing availability of limiting nutrients via excretion or sloppy feeding (Peduzzi \& Herndl 1992; Sterner et al. 1995; Carrillo et al. 1996b).

It is known that the seasonal succession of phytoplankton species involves complex interactions, where physical, chemical and biotic environmental factors play a basic role (Reynolds 1989). However there is controversy on how variations in the limiting nutrients affect phytoplankton succession. Meanwhile some studies evidenced the important effect of external (climatic) processes (Elser et al. 1995), other studies have considered that such forces exert negligible influence to phytoplankton succession (Sarnelle 1993; Berman et al. 1995).
In this paper we describe inter-annual and seasonal variations in the structure of the planktonic community of the oligotrophic Lake La Caldera. We assess the relationships among biotic and abiotic components and the role of variations in the precipitation regime as key factor to understand changes in the planktonic structure.

\section{MATERIALS AND METHODS}

\subsection{Sampling and laboratory procedure}

Field samples were taken over the entire ice-free period, from late May to early November in 1995, and from July to early November in 1996 and 1997. A total of 27, 12 and 16 field samplings were carried out for the three consecutive years. Sampling was conducted weekly at one $(1 \mathrm{~m})$ and four $(0.5,5,8$ and $10.5 \mathrm{~m})$ depths at a central deepest station during 1995 and 1996-97, respectively. Temperature and $\mathrm{pH}$ were measured using a YSI probe. Organism samples were taken with a 6-L Van Dorn sampler. Chemical and biologic samples were processed following MOLAR Project protocols, including the recommended biomass conversion factors (Straškrabová et al. 1999, this issue).

Concentrate bacterial sub-samples were set on electron microscopy grids (400-mesh $\mathrm{Cu}$ grids) with colloidon film, stained with $1 \%$ uranyl acetate and examined at a magnification of $\times 20,000$ in TEM equipment. Cells and calibration grids were pictured and the images were scanned. Length and width of $>30$ bacteria were measured from scanned images using Corel Photo-Paint program. Cell volumes were calculated as $\left(\mathrm{W}^{2} \mathrm{~L} \pi\right) / 6$, were $\mathrm{W}$ is the width and $\mathrm{L}$ is the length of the cell. 


\section{RESULTS}

\subsection{Abiotic characterization}

During the study period La Caldera Lake showed strong inter-annual changes in its volume (depth) as a consequence of the severe drought of 1995. This was the driest year of a series of dry years (from 1988) and the driest year recorder for the last 4 decades $(395 \mathrm{~mm})$ and lake maximum depth reached only $2 \mathrm{~m}$. In addition, the ice-free period was long and comprised from midMay to early-November. The increase of precipitation during 1996 and 1997 was responsible for the recovery of the maximum lake depth $(14 \mathrm{~m})$, which was maintained within narrow limits for both years. The ice-free period for the wet years (1996-1997) was shorter than that registered in 1995.

La Caldera Lake exhibited weak thermal stratification in mid-summer, with maximum surface-bottom differences values ranging from $3.5^{\circ} \mathrm{C}$ in 1996 to $6.7^{\circ} \mathrm{C}$ in 1997. During the remaining of the season the lake had a uniform temperature profile and surface-bottom differences did not surpass $2{ }^{\circ} \mathrm{C}$. Water temperature oscillated widely in 1995 , but within a narrow range for the period of 1996-97.
$16.3 \mu \mathrm{g} \mathrm{P} \mathrm{l}^{-1}$. PP accounted $>74 \%$ of $\mathrm{P}$ fraction for this year.

Nitrogen was found mainly as inorganic forms in 1996 and during the first summer months of 1997 (DIN, dissolved inorganic nitrogen, represented more than $50 \%$ of TN, total nitrogen). However, DIN accounted $c a$ $50 \%$ and $<30 \%$ of TN, in 1995 and for the last months of 1997, respectively. DIN (and especially $\mathrm{NO}_{3}{ }^{-}$) slowly decreased over the summer of the wet years, although this tendency was not observed in 1995 (Tab. 1). According to Morris \& Lewis (1988), DIN/PT (by weight) ratio values exceeding 12 implies a strong likelihood of $\mathrm{P}$ limitation, and in fact, this was the case of La Caldera for the study period except for the sporadic atmospheric loads of P. PN (particulate nitrogen) accounted for 20$30 \%$ of TN in 1995 (from late summer) and 1997 (almost all free ice period).

\subsection{Phytoplankton}

The autotrophic community was quite simple and composed of nanoplankton species, as is characteristic for oligotrophic systems (Rott 1984 \& Carrillo 1995). Autotrophic picoplankton was absent.

During the dry year of 1995 (Fig. 1A) immediately

Tab. 1. Temperature and nutrients seasonal variation in La Caldera Lake for the study period. Values are monthly means for the water profile.

\begin{tabular}{|c|c|c|c|c|c|c|c|c|c|}
\hline DATE & $\begin{array}{c}\mathrm{T} \\
\left({ }^{\circ} \mathrm{C}\right)\end{array}$ & $\begin{array}{c}\mathrm{NO}_{3} \\
\left(\mu \mathrm{g} \mathrm{N}^{-1}\right)\end{array}$ & $\begin{array}{c}\text { DIN } \\
\left(\mu \mathrm{g} \mathrm{N}^{-1}\right)\end{array}$ & $\begin{array}{c}\mathrm{TN} \\
\left(\mu \mathrm{g} \mathrm{N}^{-1}\right)\end{array}$ & $\begin{array}{c}\mathrm{PN} \\
\left(\mu \mathrm{g} \mathrm{N} \mathrm{l}^{-1}\right)\end{array}$ & $\begin{array}{c}\mathrm{TP} \\
\left(\mu \mathrm{g} \mathrm{P}^{-1}\right)\end{array}$ & $\begin{array}{c}\mathrm{PP} \\
\left(\mu \mathrm{g} \mathrm{Pl}^{-1}\right)\end{array}$ & DIN:TP & NT:PT \\
\hline May-95 & 12.0 & 166.3 & 259.9 & 473.2 & 30.9 & 6.7 & 5.1 & 48.6 & 74.0 \\
\hline June-95 & 12.5 & 122.8 & 133.3 & 311.1 & 16.2 & 4.9 & 3.6 & 37.1 & 62.8 \\
\hline July-95 & 15.4 & 142.1 & 151.8 & 328.6 & 11.9 & 5.9 & 3.7 & 80.8 & 57.7 \\
\hline August-95 & 14.0 & 233.4 & 238.2 & 575.0 & 128.7 & 9.9 & 8.0 & 31.0 & 58.1 \\
\hline September-95 & 7.5 & 297.2 & 301.0 & 620.2 & 64.7 & 12.7 & 8.5 & 35.9 & 50.2 \\
\hline October-95 & 6.9 & 277.5 & 282.6 & 665.8 & 85.8 & 5.2 & 4.7 & 68.3 & 165.9 \\
\hline November-95 & 4.2 & 286.5 & 289.2 & 612.3 & 129.5 & 2.3 & 2.3 & 123.9 & 262.4 \\
\hline July-96 & 1.6 & 381.0 & 393.9 & 617.2 & 26.4 & 4.6 & 2.1 & 87.3 & 135.7 \\
\hline August-96 & 6.5 & 271.9 & 280.5 & 480.1 & 8.9 & 5.4 & 3.4 & 53.6 & 90.5 \\
\hline September-96 & 7.7 & 228.0 & 239.3 & 456.7 & 18.4 & 11.4 & 4.1 & 40.9 & 77.6 \\
\hline October-96 & 6.0 & 214.6 & 229.8 & 383.0 & 31.1 & 3.6 & 2.5 & 64.4 & 107.3 \\
\hline June-97 & 1.2 & 231.5 & 255.9 & 308.9 & 31.1 & 1.9 & 1.0 & 139.5 & 181.9 \\
\hline July-97 & 5.5 & 205.6 & 213.5 & 325.4 & 45.2 & 4.2 & 3.0 & 52.8 & 80.8 \\
\hline August-97 & 11.5 & 128.6 & 136.0 & 361.8 & 130.3 & 6.5 & 4.1 & 21.8 & 56.9 \\
\hline September-97 & 11.6 & 103.7 & 108.0 & 233.8 & 78.6 & 3.8 & 3.0 & 29.9 & 62.8 \\
\hline October-97 & 7.7 & 83.4 & 90.9 & 284.7 & 129.1 & 4.1 & 2.8 & 23.1 & 71.9 \\
\hline
\end{tabular}

During the wet years, total phosphorus (TP) usually ranged between 3.3 and $7.3 \mu \mathrm{g} \mathrm{P}^{-1}$. However, a strong increase was punctually registered in the lake in September of 1996, as a result of the Saharan dust input associated to atmospheric events, that resulted in an increase of about 10 fold the $\mathrm{P}$ of the lake (TP $>32 \mu \mathrm{g} \mathrm{P}$ $\mathrm{l}^{-1}$; TDP, total dissolved phosphorus, $>25 \mu \mathrm{g} \mathrm{P}^{-1}$ ).

Particulate phosphorus (PP) was the dominant $\mathrm{P}$ fraction $(>55 \%)$, except for the above mentioned increase, when PP accounted for less than 20\%, and TDP over $80 \%$. TP was (in average) higher in 1995 than during the wet years (Tab. 1) and ranged from 2.3 to after thaw and till early-June, Chrysophyceae (Chromulina nevadensis and Ochromonas sp.) was the main developing group (>80\% of phytoplankton abundance). From early-June, phytoplankton community was dominated by non-flagellated Chlorophyceae species (Chlorella sp.). In mid-summer, phytoplankton density reached the highest values $\left(>75,600\right.$ cells $\left.\mathrm{ml}^{-1}\right)$ and Cyanarcus sp. accounted for more than $40 \%$ of total cell abundance. By the end of the ice-free period phytoplankton abundance sharply decreased $(<4000$ cells $\mathrm{ml}^{-1}$ ), and both Chlorella sp. and Ochromonas sp. dominated the autotrophic community. Other species, some 
of benthic origin, were also represented (e.g. Amphidinium sp.; Navicula sp.; filamentous green algae Spirogyra sp.).
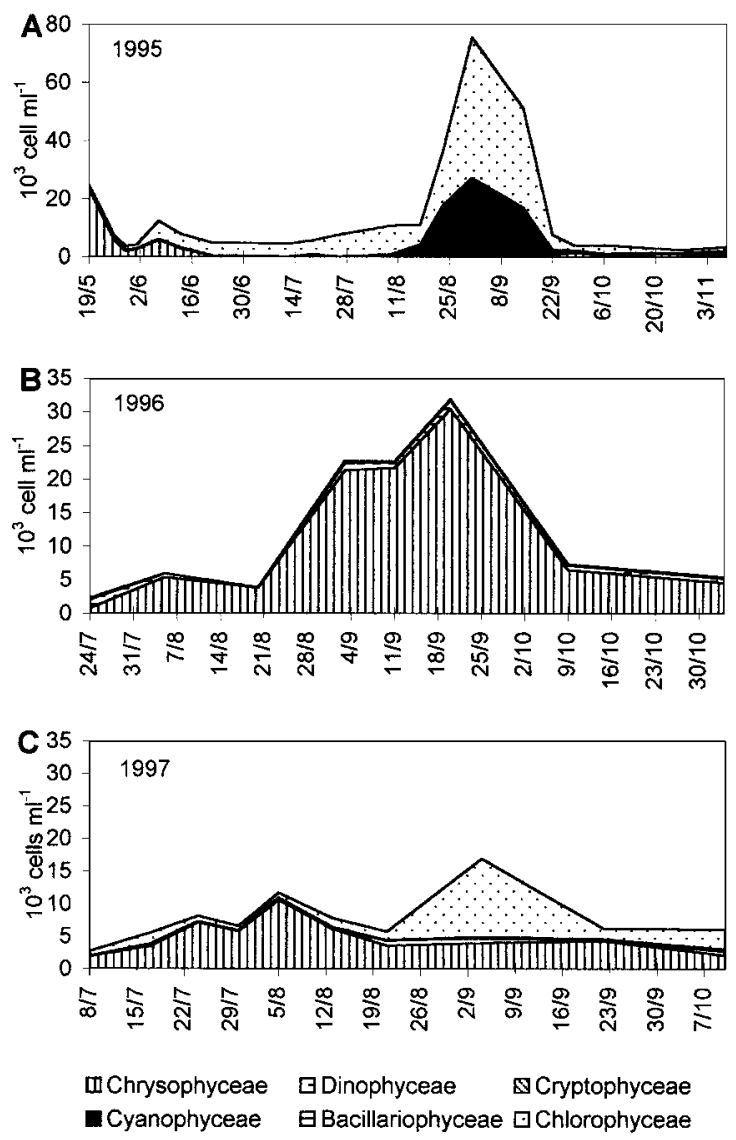

Fig. 1. Inter-annual and seasonal variation in the abundance of taxonomic phytoplankton groups. (A) 1995; (B) 1996; (C) 1997. Values are means for the water profile.

Phytoplankton community was dominated by Chromulina nevadensis for most of the ice-free period of 1996 (Fig. 1B), and from thaw to late August in 1997 (Fig. 1C), when it was replaced by Chlorella sp. which became the dominant species for a moderate period of time. Chrysophyceae reached its maximum density and biomass values in September of 1996: 21,000-30,400 cells $\mathrm{ml}^{-1}$ and $>55 \mu \mathrm{g} \mathrm{C}^{-1}$, respectively (average values for the water column), immediately after a dust deposition event. Both Chrysophyceae and Chlorophyceae reached lower densities ( $\mathrm{ca}$ 12,000 cells $\mathrm{ml}^{-1}$ ) and accounted $>80 \%$ and $>60 \%$ of total algal biomass, respectively, in 1997 (Fig. 1C).

Other less important species, such as Amphidinium sp. (Dinophyceae), Rhodomonas minuta (Cryptophyceae), Ochromonas sp. (Chrysophyceae) and Cyanarcus sp. (Cyanophyceae) developed during both wet years.

Phytoplankton seasonal succession showed the same basic pattern at all depths in 1996 and 1997. However, there were moderate differences on the water profile in both abundance and biomass of major phytoplankton groups. Highest values of abundance and biomass of the dominant algae species were reached after a dust event (September) and particularly at the surface of the water during the wet years. On the other hand, it is remarkable the high values of phytoplankton biomass $\left(257 \mu \mathrm{g} \mathrm{C}^{-1}\right)$ at the bottom depth immediately after thaw, in 1996. The development of a Cryptomonas sp. (Cryptophyceae) with a large cell volume $\left(1730 \pm 300 \mu \mathrm{m}^{3}\right)$ was responsible for this situation, although abundance was less than $10 \%$.

Chromulina nevadensis showed marked seasonal differences in size and morphology: after ice-out cells with big pyrenoids (mean cell volume $30-40 \mu \mathrm{m}^{3}$ ) developed, while cell volume gradually decreased to mean values of $5-8 \mu \mathrm{m}^{3}$ by the end of ice-free period. It is at this time when most of the cells $(>70 \%)$ showed dendricules that increased surface of the cells.

\subsection{Bacterioplankton}

The heterotrophic bacterial community of La Caldera was composed of free small coccus-like $(0.01 \pm$ $\left.0.004 \mu \mathrm{m}^{3}\right)$ and rod shaped forms $\left(0.05 \pm 0.02 \mu \mathrm{m}^{3}\right)$. Filamentous bacteria $\left(0.18 \pm 0.07 \mu \mathrm{m}^{3}\right)$ were scarce. Most coccus-forms could be identified as virus likeparticles because of their small size and poliedric shape, as similarly found for others lakes (Sommaruga et al. 1995; Pina et al. 1998).

Inter-annual changes in bacterial standing-stock variables for the period of 1995-1997 are shown in table 2. Overall, a decreasing tendency in these parameters is observed.

The seasonal dynamic of bacterial community showed limited inter-annual differences. Bacterial standing-stock parameters reached their highest values at mid-summer, with small oscillations towards the end of summer in 1995 (Fig. 2A). We observed a progres-

Tab. 2. Inter-annual changes in bacterial abundance and biomass observed during the period of 1995-1997. Values are annual means for the water profile.

\begin{tabular}{lccccccc}
\hline & \multicolumn{2}{c}{ Abundance $\left(\right.$ cells $\left.\mathrm{ml}^{-1} \times 10^{5}\right)$} & & \multicolumn{3}{c}{ Biomass $\left(\mu \mathrm{g} \mathrm{C}^{-1}\right)$} \\
\cline { 2 - 3 } \cline { 7 - 8 } Year & Average & Maximum & Minimum & & Average & Maximum & Minimum \\
\hline 1995 & 10.75 & 26.57 & 4.46 & & 10.33 & 25.53 & 4.28 \\
1996 & 5.17 & 7.50 & 1.82 & & 5.08 & 7.44 & 1.84 \\
1997 & 1.96 & 3.30 & 1.22 & & 1.92 & 3.20 & 1.19 \\
\hline
\end{tabular}


sive increase tendency of bacterial abundance at surface depths in 1996. Maximum bacterial densities were reached at bottom depths in late August for this year. Bacterial abundance varied slightly over the ice-free period of 1997 (Fig 2C). Bacteria showed a fairly homogeneous vertical distribution with slight inter-depth differences in abundance and biomass (Fig. 3).
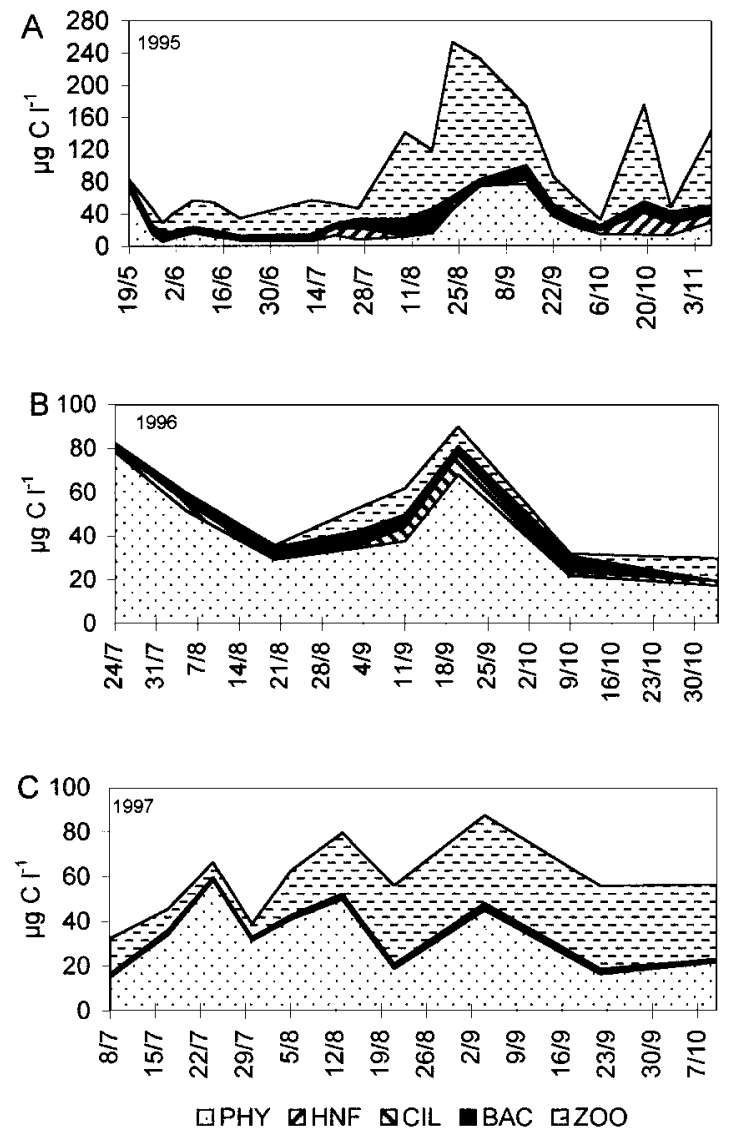

Fig. 2. Inter-annual and seasonal variation in the biomass of trophic groups. (A) 1995; (B) 1996; (C) 1997. Values are means for the water profile. PHY: Phytoplankton; HNF: Heterotrophic nanoflagellates; CIL: Ciliates; BAC: Bacteria; ZOO: Zooplankton.

\subsection{Heterotrophic nanoflagellates and ciliates}

The year of 1995 sets up a reference time with regard to the presence of heterotrophic nanoflagellates (HNF) and ciliates, not significantly represented in the lake before this year. Two distinct peaks of HNF were observed (Fig. 2A) during July (2000-5000 cells $\mathrm{ml}^{-1}$ ) and by the end of the ice-free period (reaching values of up to 17,000 cells $\mathrm{ml}^{-1}$ ).

Ciliates (Oligotrichidae) reached their highest density values immediately after the thaw $\left(>4\right.$ cells $\left.\mathrm{ml}^{-1}\right)$ and in August $\left(>3\right.$ cells ml ${ }^{-1}$ ) of 1995 . Nevertheless, HNF populations were very scarce $\left(<20\right.$ cells $\left.\mathrm{ml}^{-1}\right)$ and ciliates increased considerably $\left(>40\right.$ cells $\left.\mathrm{ml}^{-1}\right)$ in mid-
September of 1996 (Fig. 2B). Finally, both groups were scarcely represented in 1997 (Fig. 2C).

\subsection{Zooplankton}

Zooplankton community composition was simple and we did not observe major inter-annual differences in composition. A calanoid copepod, Mixodiaptomus laciniatus, was the main zooplankton species. Rotifers (Hexarthra bulgarica) and cladocerans (Daphnia pulicaria) were usually present at low abundance.

Zooplankton abundance varied significantly among years, with lower densities $\left(<1\right.$ ind $\left.1^{-1}\right)$ in 1996 , in comparison to 1995 and 1997 (29 and 20 ind $\mathrm{l}^{-1}$, respectively).

Seasonal biomass changes in zooplankton (mean values for the water column) ranged from 2.5 to 192.5

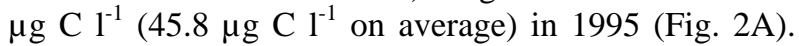
Although $H$. bulgarica contributed $c a 10 \%$ on average to zooplankton biomass, this species dominated the zooplankton community ( $\mathrm{ca} 50 \%$ biomass and $>80 \%$ abundance) in early August and late September for the dry year of 1995. D. pulicaria was scarce and represented less than $10 \%$ of total zooplankton biomass by the end of summer $\left(<5 \mu \mathrm{g} \mathrm{C}^{-1}\right)$. Overall, M. laciniatus was the main species for the ice-free period and, in contrast to the wet years, it developed a bivoltine cycle with two hatching events that led towards two nauplii peaks during May-June (ca 70\% total zooplankton abundance) and August-September ( ca 10\% total zooplankton abundance) in 1995. Nauplii were followed by subsequent adults peaks in mid-summer ( ca $180 \mu \mathrm{g} \mathrm{C}$ $\mathrm{I}^{-1}$ ) and by the end of the ice-free period ( $c$ a $120 \mu \mathrm{g} \mathrm{C}$ $\left.1^{-1}\right)$.

M. laciniatus comprised over $90 \%$ of zooplankton abundance and biomass in 1996 and 1997. Biomass (mean values for the water column) ranged from 0.002 to $12 \mu \mathrm{g} \mathrm{C}^{-1}$ (approx. $4 \mu \mathrm{g} \mathrm{C}^{-1}$ on average) in 1996 (Fig. 2B), and from 6 to $60 \mu \mathrm{g} \mathrm{Cl}^{-1}$ (approx. $29 \mu \mathrm{g} \mathrm{C}^{-1}$ on average) in 1997 (Fig. 2C). D. pulicaria and H. bulgarica were scarce and accounted $<5 \%$ of zooplankton abundance and biomass. The development of nauplii comprised the totality of zooplankton biomass from thaw until late August when copepods reached high abundance (maximum biomass value $=11.6 \mu \mathrm{g} \mathrm{C}^{-1}$ ) in 1996. A similar but earlier dynamic was observed for 1997, with the occurrence of naupliar stages replaced by adults of the dominant species $M$. laciniatus at the beginning of August. Other copepod species such us Diaptomus cyaneus or Acanthocyclops vernalis were very scarce for these wet years.

Zooplankton showed a heterogeneous vertical distribution. Overall, species concentrated at bottom depths during the time of sampling (mid-day), and especially during sunny days when zooplankton biomass at the bottom exceeded over three times that of surface (Fig. $3)$. 

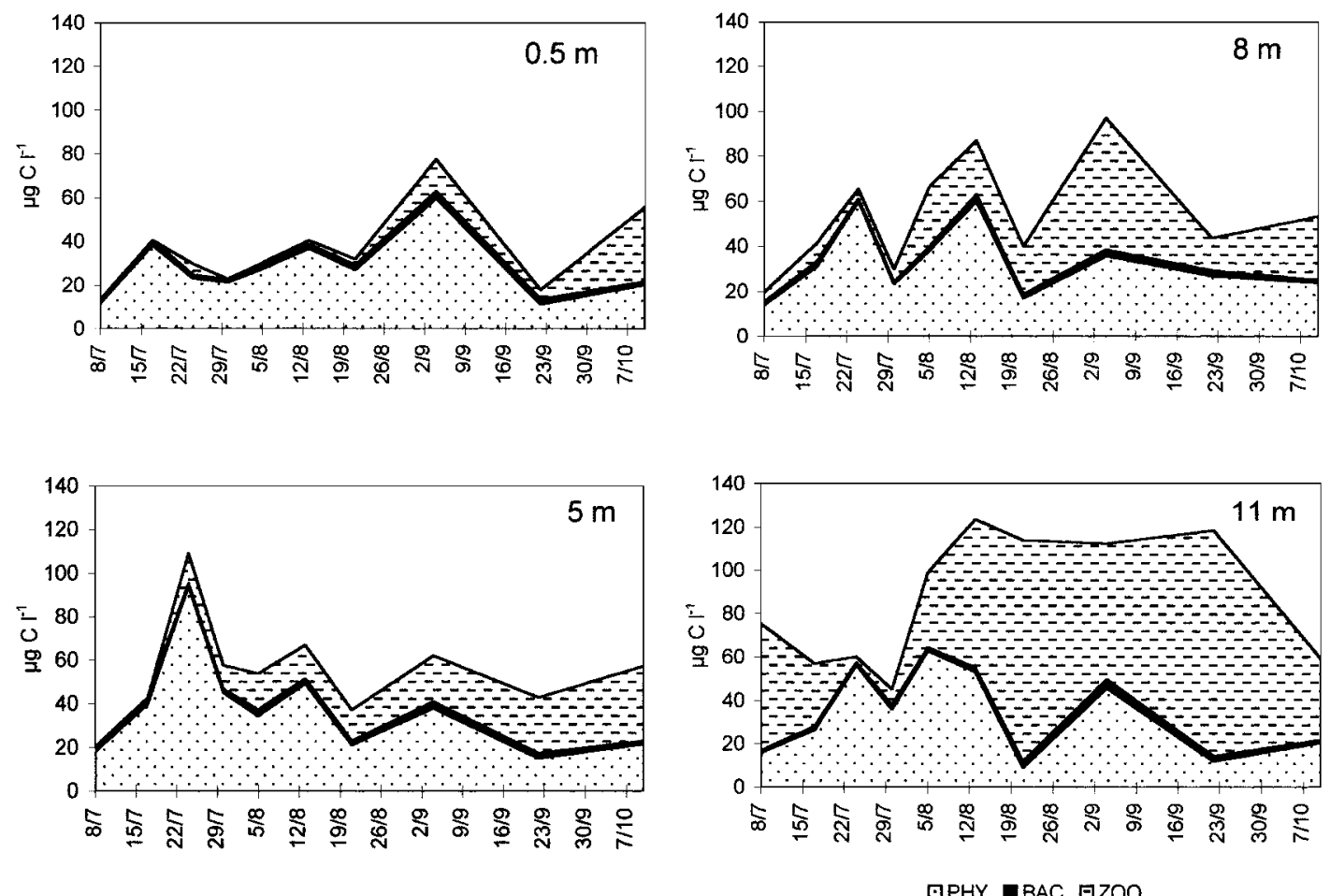

Fig. 3. Seasonal variation in the biomass of the main trophic groups during 1997 at $0.5,5,8$, and $11 \mathrm{~m}$ depth. Legend as in figure 2 .

\subsection{Biotic and non-biotic components relationship}

The autotrophic/heterotrophic $(\mathrm{A} / \mathrm{H})$ ratio showed significant differences between the dry and the wet years. Thus, values under 1 were registered during 1995, whereas this ratio averaged 5.7 and 2.2 for 1996 and 1997, respectively. The A/H ratio was always over 1 (from 1.5 to 20.3 ) in 1996, and under 1 (ranging from 0.4 to 0.6 ) towards the end of the ice-free period of 1997. A/H ratio was always over 1 after thaw.

Inter-annual changes in the contribution of trophic groups to total plankton biomass (water column average values) are summarized in table 3. Bacteria constituted a minor proportion of plankton biomass, especially for the wet years. On the other hand, phytoplankton was the main group for the wet years, but it only contributed $28 \%$ on average in 1995 , as suggested by the $\mathrm{A} / \mathrm{H}$ ratio $<1$. Zooplankton contributed significantly to the overall biological community, although being a non important fraction during 1996. HNF were only significant in 1995. Finally, and as a consequence of zooplankton scarcity, ciliates significantly contributed to the biological pool in 1996.

Our results showed that a tight relationship exists between nutrients (mainly $\mathrm{P}$ and $\mathrm{N}$ ) and phytoplankton standing-stock parameters in 1995 (Tab. 4). Heterotrophic bacteria was negatively related to phytoplankton ( $\mathrm{r}=-0.94, \mathrm{p}<0.01)$ in 1996 (Tab. 4). In 1997 (Tab. 4) algae were negatively related to $T N: T P$ ratio $(r=-0.92$, $\mathrm{p}<0.001)$, and ciliates showed an inverse relationship with zooplankton $(\mathrm{r}=-0.80, \mathrm{p}<0.01)$. Zooplankton and temperature showed a positive relationship in wet years (Tab. 4).

Tab. 3. Annual percentage biomass for each trophic group. BAC: Bacteria; CIL: Ciliates; HNF: Heterotrophic nanoflagellates; PHY: Phytoplankton; ZOO: Zooplankton.

\begin{tabular}{lccccc}
\hline Year & PHY & HNF & CIL & BAC & ZOO \\
\hline 1995 & 28.2 & 7.5 & 0.5 & 14.4 & 49.5 \\
1996 & 73.9 & 0.2 & 5.4 & 9.3 & 11.2 \\
1997 & 57.1 & 0.1 & 0.0 & 3.4 & 39.3 \\
\hline
\end{tabular}

\section{DISCUSSION}

We have included data not only from 1996 and 1997 (study years of MOLAR Project) but also from 1995. We considered of basic relevance the analysis of the period spanning these three years because of the strong changes in precipitation regime from 1995. These changes caused variations in the physical and chemical features of the lake, since inputs of allochthonous nutrients (mainly $P$ ) occur with the thaw (Carrillo et al. 1996a), but also with the sporadic atmospheric depositions events associated to massive dust outbreaks from Sahara desert (Talbot et al. 1986; Guerzoni et al. 1997; Moulin et al. 1997a, 1997b). The peculiar water regime plus the influence of the atmospheric external forces 
might be fundamental to plankton structure and dynamics.

Tab. 4. Results of the intra-annual correlation analysis among abiotic and biotic components (r values). ns: not significative. BAC: Bacteria; BIO: Biotic components; CIL: Ciliates; HNF: Heterotrophic nanoflagellates; MVB: Micro-bacterivorous; PHY: Phytoplankton; ZOO: Zooplankton. A: Abundance; B: Biomass. TP: Total phosphorus; PP: Particulate phosphorus; $\mathrm{TN}$ : Total nitrogen; $\mathrm{T}$ : Temperature. ${ }^{*} \mathrm{p}<0.05, * * \mathrm{p}<0.01, * * * \mathrm{p}<0.001$.

\begin{tabular}{|c|c|c|c|c|}
\hline & \multicolumn{4}{|c|}{1995} \\
\hline & PHY B & CIL B & $\mathrm{ZOO} \mathrm{A}$ & $\mathrm{BIO} \mathrm{B}$ \\
\hline HNF A & ns & $-0.61 *$ & $-0.62 * *$ & - \\
\hline $\mathrm{TP}$ & $0.73 * * *$ & $0.55^{*}$ & ns & $0.58^{* *}$ \\
\hline PP & $0.75 * * *$ & $0.68 * *$ & ns & $0.61 * *$ \\
\hline \multirow[t]{3}{*}{$\mathrm{TN}$} & $0.75 * * *$ & ns & ns & $0.63 * *$ \\
\hline & \multicolumn{4}{|c|}{1996} \\
\hline & $\mathrm{BAC} B$ & BAC A & MVB A & ZOO A \\
\hline PHY B & $-0.94 * *$ & $-0.94 * *$ & ns & ns \\
\hline PHY A & ns & ns & $0.79 *$ & ns \\
\hline PN & $0.90 *$ & $0.90 *$ & ns & ns \\
\hline \multirow[t]{3}{*}{$\mathrm{T}$} & ns & ns & ns & $0.85^{*}$ \\
\hline & \multicolumn{4}{|c|}{1997} \\
\hline & PHY B & MBV A & $\mathrm{ZOOA}$ & ZOO B \\
\hline PHY B & ns & $0.79 * *$ & ns & ns \\
\hline CIL A & ns & ns & $-0.78^{*}$ & $-0.80 * *$ \\
\hline TN:TP & $-0.92 * * *$ & $-0.85^{* *}$ & ns & ns \\
\hline $\mathrm{T}$ & ns & ns & $0.87 * *$ & ns \\
\hline
\end{tabular}

\subsection{Phytoplankton}

Until 1995, phytoplankton seasonal succesion showed a quite definite pattern: after thaw, flagellates (Chrysophyceae: Chromulina nevadensis; Dinophyceae: Amphidinium sp.) dominated, and were replaced by a large population of non colonial Cyanophyceae (Cyanarcus sp.) during mid-summer. At this time (August), the abundance of phytoplankton was maximum with values ranging 1700-5000 cells ml ${ }^{-1}$ in 1986 (Carrillo et al. 1995), 8000-14,000 cells ml ${ }^{-1}$ in 1992-93 (Carrillo et al. 1996a), Cyanarcus sp. accounting for more than 60$90 \%$ of phytoplankton biomass (Carrillo et al. 1995, 1996a). At the end of the summer, flagellates (C. nevadensis, Amphidinium sp.) were predominant again. Other species were less important (Chlorophyceae: Oocystis lacustris; Bacillariophyceae: Cyclotella sp.). The consistency of this pattern over the years is well documented for this lake (Martínez 1977; Carrillo 1989; Reche 1995).

Total algal abundance increased about 7.5 fold in 1995 with respect to previous years. Chrysophyceae was replaced by non-flagellate Chlorophyceae species (Chlorella sp.), even though Cyanarcus sp. accounted for about $40 \%$ of total algal abundance at mid-summer (Fig. 1A). We believe that this shift could be related to the high $P$ levels (Tab. 1) in a year (1995) when resuspension processes were significant due to the small lake volume. As already suggested by Currie (1990), the positive correlation found between either TP or PP with algal biomass (Tab. 4) indicates the increase of $\mathrm{P}$ avail- ability to algae. Such an increase could favour the competitive development of Chlorella sp. over Chrysophyceae species, as the first thrive in relatively rich phosphorus habitats (Reynolds 1984, 1998). Moreover, the increased phosphorus levels can surpass a critical threshold above which $\mathrm{P}$ would not be limiting to maximum algal growth rates, in spite of the high N/P ratio (Reynolds 1992, 1998).

We found that temperature is a second key factor that could explain the development of Chlorella sp. The results of the stepwise regression analysis showed that about $16 \%(\mathrm{p}<0.05)$ of the variance in Chlorophyceae abundance was explained by temperature only (TP and temperature together explained $56 \%$ of variance, $p$ $<0.01$ ) in 1995. In this context, we found that Chlorella sp. developed when water temperature surpass $10^{\circ} \mathrm{C}$ on average (1995 and second half of 1997).

The recovery of the lake volume led towards $C$. nevadensis (Chrysophyceae) domination of the phytoplankton community during 1996 (Fig. 1B) and the first half of 1997 (Fig. 1C). The absence of a significant relationship between TP or TDP with any biological parameter suggests the insignificant role played by phosphorus in controlling plankton seasonal dynamics and hence the weakness of bottom-up forces during this period. Furthermore, most of the phosphorus associated to external loads was presumably not taken up by plankton but lost to the sediment (Tab. 1), since much of this phosphorus is adsorbed to grain particles (Avila et al. 1997; Perry et al. 1997). The scarce zooplankton during this period favoured $C$. nevadensis growth because of zooplankton effectiveness in controlling phytoplankton via grazing (Carrillo et al. 1990, 1991b, 1995).

When Chrysophyceae dominated the phytoplankton community of La Caldera, Reche et al. (1997) found that phosphorus released by zooplankton, could satisfy between 74 and $316 \%$ of the sestonic minimum $P$ demands. Due to the extremely low zooplankton abundance and biomass values during 1996, zooplankton could only satisfy between 1.24 and $41 \%$ of the $P$ algae demands (Villar-Argaiz et al. submitted). It is reported that aquatic bacteria are rich in phosphorus and show low N:P ratio (Andersen et al. 1986; Elser et al. 1995; Fagerbakke et al. 1996). As a consequence, much of algae phosphorus demands might be satisfied by bacterial phosphorus through the possible bacterivory shown by C. nevadensis (Carrillo et al. 1991a), as previously reported for other Chrysophyceae species (Porter 1988, Salonem \& Jokinen 1988, Nygaard \& Tobiesen 1993). The negative relationship found between algal biomass and bacterial abundance or biomass $(\mathrm{r}=-0.94, \mathrm{p}<0.01$, Tab. 4) and the morphologic pattern showed by $C$. nevadensis further support this hypothesis. Besides, the positive relationship between algal standing-stock parameters and heterotrophic micro-bacterivorous (HNF plus ciliates) abundance (1996: $r=0.79, \mathrm{p}<0.05 ; 1997$ : $\mathrm{r}=0.79, \mathrm{p}<0.01$, Tab. 4), suggests that two potential 
bacterivorous communities covariate with respect to a common factor, which we hypothesize as bacteria.

The Cryptomonas sp. population developed at the bottom just after thaw, what is consistent with its ability to growth during vernal conditions (Reynolds 1984). Moreover, the growth of Cryptomonas sp. occurred at a period of zooplankton scarcity, due to the high grazing susceptibility of this species. (Reynolds 1998).

Maximum phytoplankton densities dropped during 1997 (approx. 10000-15000 cells ml ${ }^{-1}$ ), and was consistent with the recovery of zooplankton populations (mainly calanoids), and consequently with the increase of the zooplankton grazing pressure (Carrillo et al. 1990, 1991b, 1995).

C. nevadensis was the dominating species from thaw to mid-August, when Chorella sp. began to replace it, coinciding with water temperature values above $10{ }^{\circ} \mathrm{C}$ and the recovery of the zooplankton community. Algal biomass was negatively related to TN/TP ratio $(r=-0.92$ $\mathrm{p}<0.001$, Tab. 4) suggesting a seasonal growth pattern controlled by phosphorus. Since allochthonous phosphorus inputs were low in 1997, much of the $P$ availability in the pelagic zone should originate from zooplankton recycling which could satisfied about $335 \%$ of algal minimum $\mathrm{P}$ requirements (Villar-Argaiz et al. submitted) Moreover, from mid-summer, the DIN/TP ratio reached similar values to those registered in 1995, indicating a fall in the severity of P limitation, what could support Chlorophyceae development.

During the wet years, the usual development of Cyanarcus sp. at mid-summer (Carrillo et al. 1995) was absent. It is well known that Cyanophyceae thrive in relatively warm waters (Smith 1985; Reynolds 1984, 1998). The water temperature in mid-summer of years before 1996 reached values above $14{ }^{\circ} \mathrm{C}$ (Carrillo et al. 1996a), whereas water was always below $12^{\circ} \mathrm{C}$ for the same period of 1996 and 1997. For this reason, we interpreted that the relatively low water temperature values $\left(<14{ }^{\circ} \mathrm{C}\right)$ registered at any time during 1996 and 1997 could explain the absence of Cyanarcus, meanwhile other more temperature tolerant taxonomic group (Chrysophyceae, Chlorophyceae) could successfully growth.

\subsection{Bacterioplankton}

Because of the small cell size, bacterial contribution to overall planktonic biomass was low, specially during the wet years ( $<10 \%$ on average). A clear diminishing pattern in bacterial standing-stock parameters is observed (Tab. 2) from 1995, with values in the lowest limit of the range characteristic for oligotrophic lakes (Thomas et al. 1991a, 1991b; Reche et al. 1994; Ochs et al. 1995).

The net results of bottom-up (mainly P-availability) and top-down (grazing) forces determine the variation in bacterioplankton parameters (Pace \& Cole 1994).
However, the absence of a significant relationship between bacterial standing-stock parameters and other biotic or abiotic components does not clarify for the relative strength of the above controls in 1995. Nevertheless, several facts might support for top-down control on bacteria for the wet years. First, we found a strong negative relationship between algal biomass (mainly Chrysophyceae) and bacteria $(\mathrm{r}=-0.94, \mathrm{p}<0.01$, Tab. 4) in 1996; second, the low bacterial densities registered during 1997 (Fig. 2C), coincides with a phytoplankton community dominated by $C$. nevadensis (at least during the first half of the ice-free period) and with high zooplankton densities. In this context, Reche (1995) found that $M$. laciniatus indeed grazed on bacteria. Finally, the mean bacterial cell size $\left(c a 0.03 \mu^{3}\right)$ was among the lowest found for natural bacterioplankton (Ammerman et al. 1984; Lee \& Fuhrman 1987; Ochs et al. 1995). This low bacterial cell size might be the result of an intense grazing pressure, since phagotrophic nanoflagellates and ciliates can graze selectively on larger bacterioplankton cells (Anderson et al. 1986; González et al. 1990; González 1996; Pernthaler 1996). In addition, it has been reported the presence of large filamentous bacteria resistant to protistan grazing (Jürgens \& Güde 1994; Sommaruga \& Psenner 1995). Our results indicate the presence of such filamentous bacteria, but in low densities ( $<2 \%$ of total bacteria abundance), which could suggest zooplankton selective predation (Güde 1988; Jürgens et al. 1994).

\subsection{Heterotrophic nanoflagellates and ciliates}

HNF populations were significantly present only in 1995 (Fig. 2A) when the increase in $P$ led to a higher diversification of the plankton community. The negative relationship between $\mathrm{HNF}$ and ciliates on a seasonal scale $(r=-0.61, p<0.05)$ suggests a competitive exclusion for a common resource (bacteria). Also, HNF populations could be controlled by zooplankton (potential HNF grazer) as suggested by the negative relationship between both groups abundance $(\mathrm{r}=-0.62, \mathrm{p}$ $<0.01$ ).

In Lake La Caldera, ciliate populations might be subject to strong top-down control by zooplankton. This view agrees well with the negative relationship found (1997) between ciliates abundance and zooplankton biomass $(\mathrm{r}=-0.80, \mathrm{p}<0.01)$ and abundance $(\mathrm{r}=-0.78, \mathrm{p}$ $<0.05)$. This could explain the large ciliate development registered in 1996 coinciding with the extremely low zooplankton densities. Furthermore, in most previous papers ciliates have been very scarce in La Caldera, whereas zooplankton have been well represented (Carrillo et al. 1995; Reche et al. 1997). Several studies showed that protozoans are excellent preys with high nutritional value exploited by zooplankton (Porter et al. 1979; Stoecker \& Capuzzo 1990; DeBiase et al. 1990; Gifford 1991; Cruz-Pizarro et al. 1994). 


\subsection{Zooplankton}

The $P$-limitation conditions in this system can help to explain the dominance of calanoids copepods over cladocerans, since the latter are expected to dominate in fishless systems (Gliwicz 1985; Cruz-Pizarro et al. 1994). Calanoid copepods show higher $N: P$ ratios and lower $P$ requirements than cladocerans (Andersen \& Hessen 1991; Villar-Argaiz et al. in press), so they would be better adapted to live in $P$-limited environments. On the other hand, H. bulgarica (Rotifers), with lower N:P ratios (Villar-Argaiz et al. submitted), developed significantly only during 1995, since phosphorus availability was higher than measured in wet years and the bacterioplankton community (their potential preys) showed the highest density values for the three years of the study period. It is likely that the increase in both $P$ availability and ice-free season duration were responsible for M. laciniatus bivoltine cycle, since nauplii show higher $P$-requirements than copepodites or adults (Carrillo et al. 1996a, 1996b; Villar-Argaiz et al. in press).

The low specific growth rates of $M$. laciniatus (Cruz-Pizarro 1981a), as expected from the relatively high N:P ratio (Sterner 1995; Elser et al. 1996), led towards the slow recovery process until "normal" zooplankton abundance in 1997. Moreover, since temperature and zooplankton standing-stock parameters covaried positively (Tab. 4) it is possible that the low water temperature values registered during wet years might have conditioned this slow recovery process. Thus, during 1997, zooplankton densities and biomass values were similar to those registered before 1995 (Cruz-Pizarro 1981b; Carrillo 1989; Reche 1995, Carrillo et al. 1995).

The heterogeneous vertical distribution shown by zooplankton, in a large proportion at bottom depths during mid-day (Fig. 3), is consistent with the direct migratory behaviour pattern characteristic of zooplankton in La Caldera (Carrillo et al. 1991b).

\subsection{Autotrophic:Heterotrophic ratio}

Input of allochthonous organic carbon into the Lake are negligible (Reche et al. 1996) and, therefore, the system is considered autotrophic. Interestingly, the $\mathrm{A} / \mathrm{H}$ ratio showed values under 1 during the dry year of 1995 , indicating the presence of relatively lower phytoplankton standing stock but with a fairly high production, which ultimately could support a complex heterotrophic community (Reynolds 1984; Stegmenn \& Peinert 1984). In contrast, A/H ratios over 1 were found after thaw during the wet years, except for late summer of 1997 coinciding with zooplankton recovery.

\section{ACKNOWLEDGMENTS}

We thank Dr C. Callieri for her critical reading of the manuscript and for her valuable suggestions. This work was supported by MOLAR (Mountain Lake
Research) Project EC Contract Number ENV4 CT950007 and CICYT AMB 97-996 Project.

\section{REFERENCES}

Ammerman, J.W., J.A. Fuhrman, A. Hagström \& F. Azam. 1984. Bacterioplankton growth in seawater. I. Growth kinetics and cellular characteristics in seawater cultures. Mar. Ecol. Prog. Ser. 18: 31-39.

Andersen, O.K., J.C. Goldman, D.A. Caron \& M.R. Dennet. 1986. Nutrient cycling in a microflagellate food chain: 3 . Phosphorus dynamics. Mar. Ecol. Prog. Ser., 31: 47-55.

Andersen, T. \& D.O. Hessen. 1991. Carbon, nitrogen, and phosphorus-content of fresh-water zooplankton. Limnol. Oceanogr., 36: 807-814.

Andersson, A., U. Larsson \& A. Hagström. 1986. Size-selective grazing by a microflagellate on pelagic bacteria. Mar. Ecol. Prog. Ser., 33: 51-57.

Avila, A., I. Queraltmitjans \& M. Alarcón. 1997. Mineralogical composition of African dust delivered by red rains over Northeastern Spain. J. Geophys. Res. Atmos., 102: 21977-21996.

Beaver, J.R. \& T.L. Crisman. 1982. The trophic response of ciliate protozoans in freshwater lakes. Limnol. Oceanogr., 27: 246-253.

Berman, T., L. Stone, Y.Z. Yacobi, B. Kaplan, M. Schlichter, A. Nishri \& U. Pollingher. 1995. Primary production and phytoplankton in Lake Kinneret - A long-term record (1972-1993). Limnol. Oceanogr., 40: 1064-1076

Carrillo, P. 1989. Análisis de las interacciones tróficas en el plancton de un sistema oligotrófico. $\mathrm{PhD}$. Thesis. University of Granada: 212 pp.

Carrillo, P., L. Cruz-Pizarro \& P. Sánchez-Castillo. 1990. Analysis of phytoplankton-zooplankton relationships in an oligotrophic lake under natural and manipulated conditions. Hydrobiologia, 200/201: 49-58.

Carrillo, P., L. Cruz-Pizarro \& P. Sánchez-Castillo. 1991a. Aportación al conocimiento del ciclo biológico de Chromulina nevadensis. Acta Botanica Malacitana, 16: 19-26.

Carrillo, P., P. Sánchez-Castillo \& L. Cruz-Pizarro. 1991b. Coincident zooplankton and phytoplankton diel migrations in a high mountain lake (La Caldera, Sierra-Nevada, Spain). Arch. Hydrobiol., 122: 57-67.

Carrillo, P., I. Reche \& L. Cruz-Pizarro. 1996a. Intraspecific stoichiometric variability and the ratio of nitrogen to phosphorus resupplied by zooplankton. Freshwat. Biol., 36: 363-374.

Carrillo, P., I. Reche \& L. Cruz-Pizarro. 1996b. Quantification of the phosphorus released by zooplankton in an oligotrophic lake (La Caldera, Spain) - Regulating factors and adjustment to theoretical-models. J. Plankton Res., 18: 1567-1586.

Carrillo, P., I. Reche, P. Sánchez-Castillo \& L. Cruz-Pizarro. 1995. Direct and indirect effects of grazing on the phytoplankton seasonal succession in an oligotrophic lake $J$. Plankton Res., 17: 1363-1379.

Cruz-Pizarro, L. 1981a. Biomasa y producción de Mixodiaptomus laciniatus (Copepoda, Calanoida) en el lago de La Caldera (Sierra Nevada, Granada). In: Narcis Prat (Ed.). Actas del Primer Congreso Español de Limnología: 115124.

Cruz-Pizarro, L. 1981b. Estudio de la comunidad zooplanctónica de un lago de alta montaña (La Caldera, Sierra Nevada, Granada). PhD. University of Granada: $186 \mathrm{pp}$.

Cruz-Pizarro, L., I. Reche \& P. Carrillo. 1994. Plankton dynamics in a high-mountain lake (Las-Yeguas, Sierra-Nevada, Spain) - indirect evidence of ciliates as food source of zooplankton. Hydrobiologia, 274: 29-35.

Currie, D.J, 1990. Large-scale variability and interactions among phytoplankton, bacterioplankton, and phosphorus. Limnol. Oceanogr., 35: 1437-1455. 
DeBiase, A.E., R.W. Sanders \& K.G. Porter. 1990. Relative nutritional value of ciliate protozoa and algae as food for Daphnia. Microb. Ecol., 19: 199-210.

Elser, J.J. \& C.R. Goldman. 1991. Zooplankton effects on phytoplankton in lakes of contrasting trophic status. Limnol. Oceanogr., 36: 64-90.

Elser, J.J., D.R. Dobberfuhl, N.A. Mackay \& J.H. Schampel. 1996. Organism size, life-history, and N-P stoichiometry. Bioscience, 46: 674-684.

Elser, J.J., T.H. Chrzanowski, R.W. Sterner, J.H. Schampel \& D.K. Foster. 1995. Elemental ratios and the uptake and release of nutrients by phytoplankton and bacteria in three lakes of the Canadian Shield. Microb. Ecol., 29: 145-162.

Elser, J.J., F.S. Lubnow, E.R. Marzolf, M.T. Brett, G. Dion \& C.R. Goldman. 1995. Factors associated with interannual and intraannual variation in nutrient limitation of phytoplankton growth in Castle Lake, California. Can. J. Fish. aquat. Sci., 52: 93-104.

Fagerbakke, K.M., M. Heldal \& S. Norland. 1996. Content of carbon, nitrogen, oxygen, sulfur and phosphorus in native aquatic and cultured bacteria. Aquat. Microb. Ecol., 10: 15-27.

Gifford, D.J. 1991. The protozoan-metazoan trophic link in pelagic ecosystems. J. Protozool., 38: 81-86.

Gliwicz, Z.M., 1985. Predation of food limitation: an ultimate reason for extinction of planktonic cladoceran species. Arch. Hydrobiol., 21: 419-430.

González, J.M. 1996. Efficient size-selective bacterivory by phagotrophic nanoflagellates in aquatic ecosystems. Mar. Biol., 126: 785-789.

González, J.M., E.B. Sherr \& B.F. Barry, 1990. Size-selective grazing on bacteria by natural assemblages of estuarine flagellates and ciliates. Appl. Environ. Microbiol., 56: 583589 .

Güde, H., 1988. Direct and indirect influences of crustacean zooplankton on bacterioplankton of Lake Constance. $\mathrm{Hy}$ drobiologia, 159: 63-73.

Guerzoni, S., E. Molinaroli \& R. Chester. 1997. Saharan dust inputs to the Western Mediterranean Sea - depositional patterns, geochemistry and sedimentological implications. Deep-Sea Research Part II - Topical Studies in Oceanography, 44: 631-654.

Jürgens, K. \& H. Gude. 1994. The potential importance of grazing-resistant bacteria in planktonic systems. Mar. Ecol. Progr. Ser., 112: 169-188.

Jürgens, K., H. Arndt \& K.O. Rothhaupt. 1994. Zooplanktonmediated changes of bacterial community structure. $\mathrm{Mi}$ crobial. Ecol., 27: 27-42.

Lee, S. \& J.A. Fuhrman. 1987. Relationships between biovolume and biomass of naturally derived marine bacterioplankton. Appl. Environ. Microbiol., 53: 1298-1303.

Martínez, R. 1977. Phytoplankton species, biomass, and diversity in lake La Caldera (S. Nevada). Acta Hidrobiol., 19: 95-107.

Morris, D.P. \& Jr.W.M. Lewis 1988. Nutrient limitation of bacterioplankton growth in lake Dillon, Colorado. Limnol. Oceanogr., 37: 1179-1192.

Moulin, C., F. Guillard, F. Dulac \& C.E. Lambert. 1997a. Long-term daily monitoring of Saharan dust load over ocean using Meteosat Isccp-B2 data. 1. Methodology and preliminary results for 1983-1994 in the Mediterranean. $J$. Geophys. Res. Atmos., 102: 16947-16958.

Moulin, C., C.E. Lambert, F. Dulac \& U. Dayan. 1997b. Control of atmospheric export of dust from North-Africa by the North-Atlantic oscillation. Nature, 387: 691-694.

Neill, W.E., 1988. Complex interactions in oligotrophic lake food webs: responses to nutrient enrichment. In: S. R. Carpenter (ed.). Complex interactions in lake communities. Springer-Verlag. New York.
Nygaard, K. \& A. Tobiesen. 1993. Bacterivory in algae - A survival strategy during nutrient limitation. Limnol. Oceanogr., 38: 273-279.

Ochs, C.A., J.J. Cole \& G.E. Likens. 1995. Population-dynamics of bacterioplankton in an oligotrophic lake. $J$. Plankton Res., 17: 365-391.

Pace, M.L. \& J.J. Cole. 1994. Comparative and experimental approaches to top-down and bottom-up regulation of bacteria. Microb. Ecol., 28: 181-193.

Peduzzi, P. \& G.J. Herndl. 1992. Zooplankton activity fueling the microbial loop - differential growth-response of bacteria from oligotrophic and eutrophic waters. Limnol. Oceanogr., 37: 1087-1092.

Pernthaler, J., B. Sattler, K. Simek, A. Schwarzenbacher \& R. Psenner. 1996. Top-down effects on the size-biomass distribution of a fresh-water bacterioplankton community. Aquat. Microb. Ecol., 10: 255-263.

Perry, K.D., T.A. Cahill, R.A. Eldred, D.D. Dutcher \& T.E. Gill. 1997. Long-range transport of North-African dust to the Eastern United-Estated. J. Geophys. Res. Atmos., 102: 11225-11238.

Pina, S., A. Creus, N. González, R. Gironés, M. Felip \& R. Sommaruga. 1998. Abundance, morphology, and distribution of planktonic virus-like particles in two high-mountain lakes. J. Plankton Res., 20: 2413-2421.

Porter, K.G., 1988. Phagotrophic phytoflagellates in microbial food webs. Hydrobiologia: 159: 89-97.

Porter, K.G., M.L. Pace \& J.F. Battey, 1979. Ciliate protozoans as links in freshwater planktonic food chains. Nature, 277: 563-565.

Psenner, R \& Zapf, F. 1990. High mountain lakes in the Alps: peculiarities and biology. In: Johannessen. M., Mosello, R \& H. Barth (eds.). Acidification processes in remote mountain lakes. Air pollution research report 20 . Commission of the European Communities. Brussels: 22-37.

Reche, I. 1995. Análisis de las conexiones entre el flujo de carbono y el reciclado de nutrientes en un sistema oligotrófico. PhD. Thesis. University of Granada. Spain: 186 pp.

Reche, I., P. Carrillo \& L. Cruz-Pizarro. 1997. Influence of metazooplankton on interactions of bacteria and phytoplankton in an oligotrophic lake. J. Plankton Res., 19: 631-646.

Reche, I., P. Sánchez-Castillo \& P. Carrillo. 1994. The principal regulating mechanism on the structure of the phytoplankton community in a high-mountain lake. Arch. Hydrobiol., 130: 163-178.

Reche, I., A. Pugnetti, L. Cruz-Pizarro \& P. Carrillo. 1996. Relationship between bacteria and phytoplankton in a high-mountain lake: Importance og the organic carbon released by pelagic algae for bacterioplankton. Arch. Hydrobiol., 48: 31-38.

Reynolds, C.S. 1984. The ecology of freshwater phytoplankton. Cambridge University Press. Cambridge. 384 pp.

Reynolds, C.S., 1989. Physical determinants of phytoplankton succession. In: U. Sommer (ed.). Plankton Ecology. Succession in plankton communities. Springer-Verlag.

Reynolds, C.S. 1992. Eutrophication and the management of planktonic algae: what Vollenweider couldn't tell us. In: D.W. Sutcliffe \& J.G. Jones (eds.). Eutrophication: research and application to water supply. Freshwater Biological Association, Ambleside, pp 4-29.

Reynolds, C.S. 1998. What factors influence the species composition of phytoplankton in lakes of different trophic status. Hydrobiologia, 370: 11-26.

Rothhaupt, K.O. 1992. Stimulation of phosphorus-limited phytoplankton by bacterivorous flagellates in laboratory experiments. Limnol. Oceanogr., 37: 750-759.

Rott, E., 1984. Phytoplankton as biological parameter for the trophic characterization of lakes. Verh. int. Ver. Limnol., 22: 1078-1085. 
Salonen, K. \& S. Jokinen, 1988. Flagellate grazing on bacteria in a small dystrophic lake. Hydrobiologia, 161: 203-209.

Sarnelle, O. 1993. Herbivore effects on phytoplankton succession in a eutrophic lake. Ecol. Monogr., 63:129-149.

Smith, V.H. 1985. Predictive models for the biomass of bluegreen algae in lakes. Water Resources Bulletin, 21: 433439.

Sommaruga, R. \& R. Psenner. 1995. Permanent presence of grazing-resistant bacteria in a hypertrophic lake. Appl. Environ. Microbiol., 61: 3457-3459.

Sommaruga, R., M. Krossbacher, W. Salvenmoser, J. Catalan \& R. Psenner. 1995. Presence of large virus-like particles in a eutrophic reservoir. Aquat. Microb. Ecol., 9: 305-308.

Stegmann, P. \& R. Peinert, 1984. Interrelations between herbivorous zooplankton and phytoplankton and their effect on production and sedimentation of organic matter in Kiel Bight. Limnologica, 15: 487-495.

Sterner, R.W. 1995. Elemental stoichiometry of species in ecosystems. In: Jones, C. and Lawton, J. (eds.). Linking species and ecosystems. Chapman and Hall, New York, pp 240-252.

Sterner, R.W., T.H. Chrzanowski, J.J. Elser \& N.B. George. 1995. Sources of nitrogen and phosphorus supporting the growth of bacterioplankton and phytoplankton in an oligotrophic Canadian Shield Lake. Limnol. Oceanogr., 40: 242-249.

Stoecker, D.K. \& J.M. Capuzzo, 1990. Predation on protozoa: its importance to zooplankton. J. Plankton Res., 12: 891908.
Talbot, R.W., R.C. Harris, E.V. Browel, G.L. Gregory, D.I. Sebacher, \& S.M. Beck. 1986. Distribution and geochemistry of aerosol in the tropical North Atlantic troposphere: relationship to Saharan dust. J. Geophy. Res. Atmos., 91: 5173-5182.

Taylor, W.D., 1984. Phosphorus flux through epilimnetic zooplankton from lake Ontario: relationship with body size and significance to phytoplankton. Can. J. Fish. aquat. Sci., 41: 1702-1712.

Thingstad, T.F. \& F. Rassoulzadegan. 1995. Nutrient limitations, microbial food webs, and biological c-pumps - suggested interactions in a p-limited Mediterranean. Mar. Ecol. Progr. Ser., 117: 299-306.

Thingstad, T.F., E.F. Skjoldal \& R.A. Bohne. 1993. Phosphorus cycling and algal-bacterial competition in Sandsfjord, Western Norway. Mar. Ecol. Progr. Ser., 99: 239-259.

Thomas, W.H., B.C. Cho \& F. Azam. 1991a. Phytoplankton and bacterial production and biomass in sub-alpine Eastern Brook Lake, Sierra-Nevada, California .1. Seasonal interrelationships between the 2 biotic groups. Arctic Alp. Res., 23: 287-295.

Thomas, W.H., B.C. Cho \& F. Azam. 1991b. Phytoplankton and bacterial production and biomass in sub-alpine Eastern Brook Lake, Sierra-Nevada, California .2. Comparison with other high-elevation lakes. Arctic Alp. Res., 23: 296302.

Villar-Argaiz, M., J.M. Medina-Sánchez, L. Cruz-Pizarro \& P. Carrillo. (1999). Life history implication of Calanoid Mixodiaptomus laciniatus in C:N:P stoichiometry. Verh. int. Ver. Limnol., 27: (in press). 